\title{
Pengaruh Partisipasi Penyusunan Anggaran terhadap Kinerja Manajerial dengan Motivasi, Komitmen Organisasi, dan Job relevant information (JRI) sebagai Variabel Moderating pada Perguruan Tinggi Swasta di Provinsi Gorontalo
}

\author{
REGINA AMALIA BUMULO ${ }^{1}$, LINTJE KALANGI ${ }^{2}$, JESSY D. L. WARONGAN ${ }^{3}$ \\ ${ }^{1,2,3}$ Program Magister Akuntansi, Fakultas Ekonomi dan Bisnis Universitas Sam Ratulangi \\ email: rereamaliabumulo@gmail.com ${ }^{1}$, lintje_kalangi ${ }^{2}$, jdmarcus@gmail.com ${ }^{3}$
}

\begin{abstract}
This research is intended to analyze the effect of budgetary participation on managerial performance, and to analyze if motivation, organizational commitment, and job relevant information are able to moderate, in terms of strengthen the effect of budgetary participation, on managerial performance in private universities in Gorontalo Province. This is a quantitative research. It employed survey method. The data were collected by distributing questionnaires to 129 respondents who are structurally positioned of those private universities. Data were analysed by moderated regression analysis (MRA). Results have shown that: (1) Budgetary participation has a positive and significant effect on managerial performance, (2) Motivation does not strengthen the effect of budgetary participation on managerial performance, (3) Organizational commitment does not strengthen the effect of budgetary participation on managerial performance, (4) Job relevant information weaken the effect of budgetary participation on managerial performance.
\end{abstract}

Keywords: Budgetary Participation, Managerial Performance, Motivation, Organizational Commitment, Job Relevant Information

\begin{abstract}
Abstrak. Penelitian ini bertujuan untuk menganalisis pengaruh partisipasi penyusunan anggaran terhadap kinerja manajerial, serta apakah motivasi, komitmen organisasi, dan job relevant information memperkuat pengaruh partisipasi penyusunan anggaran terhadap kinerja manajerial pimpinan Perguruan Tinggi Swasta di Provinsi Gorontalo. Penelitian ini menggunakan metode survey dengan pendekatan asosiatif kuantitatif. Data diperoleh dengan cara penyebaran kuesioner kepada 129 responden yang merupakan para pejabat struktural Perguruan Tinggi Swasta di Provinsi Gorontalo. Teknik analisis data yang digunakan adalah moderated regression analysis (MRA). Berdasarkan hasil analisis data dapat disimpulkan bahwa: (1) Partisipasi penyusunan anggaran berpengaruh positif dan signifikan terhadap kinerja manajerial. (2) Motivasi tidak memperkuat pengaruh partisipasi penyusunan anggaran terhadap kinerja manajerial. (3) Komitmen organisasi tidak memperkuat pengaruh partisipasi penyusunan anggaran terhadap kinerja manajerial. (4) Job relevant information memperlemah pengaruh partisipasi penyusunan anggaran terhadap kinerja manajerial.
\end{abstract}

Kata kunci: Partisipasi Penyusunan Anggaran, Kinerja Manajerial, Motivasi, Komitmen Organisasi, Job Relevant Information

\section{Pendahuluan}

Salah satu sistem pengendalian akuntansi dilakukan dengan cara membandingkan standar kinerja dengan kinerja yang dicapai. Kinerja suatu organisasi sebagian besar dipengaruhi oleh kinerja para pegawainya terutama para manajer, karena pihak manajemen suatu organisasi memiliki tanggung jawab yang besar dalam memastikan kinerja organisasi dapat dicapai dengan baik. Kustono (2003: 126) menyatakan bahwa wujud bentuk suatu anggaran seringkali digunakan sebagai standar kinerja. Oleh sebab itu, anggaran mempunyai fungsi sebagai pedoman yang digunakan untuk menilai kinerja individual manajer. Hanson (dalam Milani, 1975) menyatakan bahwa anggaran sangat bermanfaat dalam membantu manajemen untuk memenuhi fungsi-fungsinya.

Dalam proses penyusunan anggaran, sebaiknya memperhatikan berbagai aspek terkait dengan berbagai masalah perilaku karyawan yang akan melakukan pekerjaannya berdasarkan anggaran yang telah disusun. Hal ini dapat dilakukan dengan cara melibatkan para manajer dalam proses penyusunan anggaran tersebut. Pendekatan partisipatif merupakan pendekatan yang paling efektif dalam penyusunan anggaran, karena dengan adanya kerjasama serta interaksi antara manajemen puncak dengan manajemen tingkat menengah dan bawah akan menghasilkan anggaran yang benar-benar mendapat dukungan dari kedua belah pihak, sehingga tercipta komitmen yang kuat untuk melaksanakannya, dan efektivitas pelaksanaan anggaran akan terwujud sesuai dengan tujuan organisasi. Oleh karena itu, partisipasi penyusunan anggaran dinilai merupakan pendekatan yang dapat meningkatkan kinerja manajerial. 
Penelitian mengenai partisipasi penyusunan anggaran dan pengaruhnya terhadap kinerja manajerial merupakan salah satu bidang penelitian yang banyak mengalami perbedaan, bukti empiris memberikan hasil yang bervariasi dan tidak konsisten. Dalam beberapa penelitian seperti yang dilakukan oleh Brownell (1983), Ivanevich (1976), Bass and Leavitt (1963), Indriantoro (2000), Nor (2007), Eker (2009), dan Mongeri (2013) ditemukan bahwa terdapat pengaruh positif dan signifikan antara partisipasi penyusunan anggaran dengan kinerja manajerial. Sedangkan Morse and Reimer (1956), Milani (1975), Kenis (1979), Brownell and Hirst (1986) menemukan bahwa partisipasi penyusunan anggaran mempunyai pengaruh yang tidak signifikan terhadap kinerja manajerial. Sementara penelitian yang dilakukan oleh Stedry (1960), Locke and Bryan (1968), Medhayani dan Suardana (2015), Marani dan Supomo (2003) menunjukkan bahwa partisipasi dalam penyusunan anggaran mempunyai pengaruh negatif terhadap kinerja manajerial. Hasil penelitian yang masih menimbulkan perbedaan ini menarik untuk dikaji lebih lanjut menggunakan pendekatan kontinjensi (contingency approach).

Variabel motivasi digunakan untuk mengevaluasi efektivitas partisipasi penyusunan anggaran dalam konteks kinerja manajerial pada penelitian ini. Pada umumnya, individu akan bekerja keras jika memiliki motivasi. Motivasi akan menimbulkan semangat atau dorongan kepada individu untuk melakukan kegiatan dalam rangka mencapai tujuan organisasi. Motivasi merupakan hal yang penting untuk dimiliki oleh para pegawai, manajer, ataupun pimpinan dalam suatu organisasi, karena dengan motivasi yang tinggi maka pekerjaan akan dilakukan dengan lebih bersemangat dan bergairah sehingga akan dicapai suatu hasil yang optimal untuk mendukung tercapainya tujuan yang diinginkan secara efektif dan efisien.

Selanjutnya variabel komitmen organisasi juga digunakan untuk mengevaluasi efektivitas partisipasi penyusunan anggaran dalam konteks kinerja manajerial pada penelitian ini. Komitmen organisasi adalah rasa keterikatan individu dengan organisasinya (Mathieu and Zajac, 1990). Tinggi rendahnya komitmen pegawai terhadap organisasi tempat mereka bekerja sangatlah menentukan kinerja manajerial yang akan dicapai (Siagian, 2002 dalam Mongeri, 2013), sebab komitmen organisasi yang kuat akan mendorong manajer untuk berusaha keras mencapai tujuan organisasi, dan diharapkan akan meningkatkan kinerjanya. Partisipasi penyusunan anggaran yang dilakukan oleh para manajer yang memiliki komitmen organisasi tinggi akan mengarahkan kepada peningkatan kinerja manajerial (Sardjito dan Muthaher, 2007).

Variabel berikutnya yang digunakan untuk mengevaluasi efektivitas partisipasi penyusunan anggaran dalam konteks kinerja manajerial adalah job relevant information (JRI). Partisipasi penyusunan anggaran dapat memfasilitasi perolehan JRI bagi para manajer, karena proses penyusunan anggaran secara partisipatif menciptakan interaksi antar tingkatan manajemen yang menimbulkan pertukaran informasi di dalamnya, yang pada akhirnya akan mempengaruhi peningkatan kinerja manajerial (Kren, 1992).

Peran partisipasi penyusunan anggaran dalam meningkatkan kinerja manajerial juga diharapkan dapat terjadi di lingkungan perguruan tinggi, khususnya perguruan tinggi swasta (PTS). PTS merupakan suatu lembaga pendidikan tinggi yang berada di bawah naungan Kopertis. Berbeda dengan perguruan tinggi negeri (PTN) yang proses perencanaan dan pengelolaan anggarannya bergantung dan diatur oleh pemerintah melalui dana APBN, PTS memiliki otonomi sendiri dalam menentukan sistem penganggarannya. Proses penyusunan anggaran di PTS dilakukan menggunakan pendekatan partisipatif, dimana setiap tingkatan manajemen di dalamnya terlibat aktif dalam menyusun anggaran, dimulai dari manajemen tingkat bawah ke manajemen tingkat menengah, dan kemudian ke manajemen puncak.

Kualitas suatu perguruan tinggi di Indonesia, baik PTN maupun PTS dapat dilihat dari tingkat akreditasinya. Akreditasi menjadi sebuah aset penting untuk menetapkan posisi sebuah institusi perguruan tinggi/program studi dalam tataran kompetisi pengelolaan dengan institusi perguruan tinggi/program studi lainnya. Maka dari itu, peningkatan kualitas perguruan tinggi, khususnya PTS diharapkan dapat meningkatkan kualitas output berupa lulusan yang dihasilkan sehingga PTS tersebut mampu bertahan secara berkelanjutan sebagai PTS yang berkualitas, guna menghasilkan lulusan yang mampu bersaing dan memenuhi kebutuhan pasar kerja yang diharapkan oleh masyarakat. Namun pada kenyataannya, keadaan PTS di Provinsi Gorontalo belum mencerminkan harapan yang diinginkan oleh masyarakat dalam hal ketersediaan output berupa lulusan berkualitas tinggi yang siap bersaing dalam pasar kerja. Penerapan partisipasi penyusunan anggaran pada PTS menyebabkan PTS memiliki peluang untuk dapat mengendalikan organisasinya dengan lebih baik, serta meningkatkan kinerja 
manajerialnya melalui proses penyusunan anggaran secara partisipatif tersebut, sehingga diharapkan kualitas PTS dapat meningkat.

Berdasarkan latar belakang masalah tersebut, maka yang menjadi rumusan masalah dalam penelitian ini adalah: 1) Apakah partisipasi penyusunan anggaran berpengaruh positif dan signifikan terhadap kinerja manajerial?; 2)Apakah motivasi memperkuat pengaruh partisipasi penyusunan anggaran terhadap kinerja manajerial?; 3) Apakah komitmen organisasi memperkuat pengaruh partisipasi penyusunan anggaran terhadap kinerja manajerial?; 4) Apakah job relevant information (JRI) memperkuat pengaruh partisipasi penyusunan anggaran terhadap kinerja manajerial?

Tujuan yang hendak dicapai dalam penelitian ini adalah untuk menganalisis semua rumusan masalah yang ada. Penelitian ini diharapkan dapat memberikan manfaat bagi semua pihak yang berkepentingan diantaranya, yaitu 1) Hasil penelitian ini diharapkan menjadi suatu bukti empiris tentang pengaruh partisipasi penyusunan anggaran terhadap kinerja manajerial, serta tentang pengaruh partisipasi penyusunan anggaran terhadap kinerja manajerial dengan motivasi, komitmen organisasi, dan job relevant information (JRI) sebagai variabel moderating. Kemudian, hasil penelitian ini juga diharapkan dapat menjadi referensi penting bagi penelitian selanjutnya yang berkaitan; 2) hasil penelitian ini diharapkan dapat memberikan pengetahuan dan pemahaman yang lebih baik tentang pengaruh partisipasi penyusunan anggaran terhadap kinerja manajerial, serta faktor-faktor kondisional yang dapat memperkuat hubungan antara keduanya.

Gambar 1.

Kerangka Konseptual

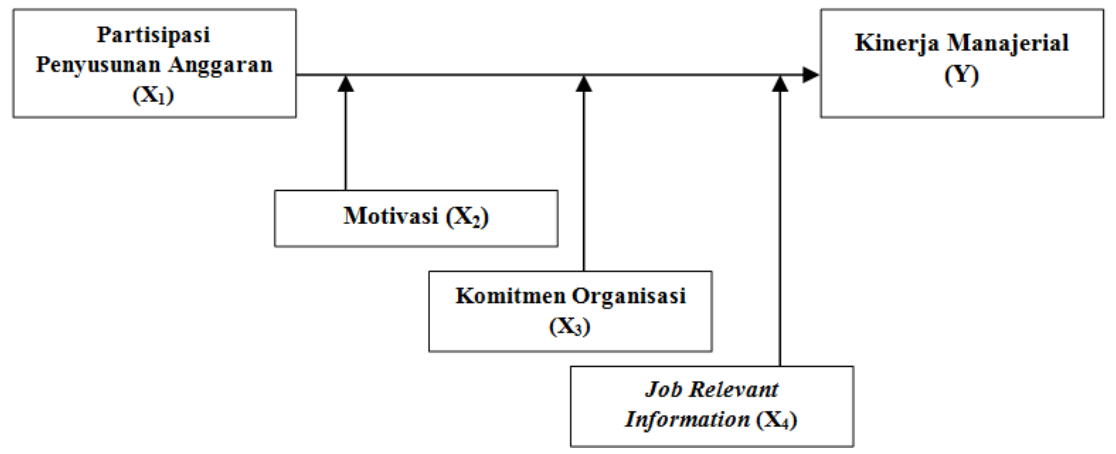

Sumber: Data Hasil Olahan (2017)

Berdasarkan Gambar 1. bentuk penelitian menunjukkan suatu pengaruh antara variabel independen atau variabel bebas yaitu Partisipasi Penyusunan Anggaran terhadap variabel dependen atau variabel terikat yaitu Kinerja Manajerial, dimoderasi oleh variabel moderating yang terdiri dari Motivasi, Komitmen Organisasi, dan Job Relevant Information.

Berdasarkan kajian teoritis, hasil-hasil penelitian terdahulu, serta kerangka pemikiran teoritis, maka peneliti merumuskan hipotesis, sebagai berikut.

\section{Pengaruh Partisipasi Penyusunan Anggaran terhadap Kinerja Manajerial}

Milani (1975) menyatakan bahwa partisipasi penyusunan anggaran dinilai dapat meningkatkan kinerja manajerial, yakni ketika tujuan telah direncanakan dan disetujui secara partisipatif, pegawai akan menginternalisasi tujuan tersebut dan mereka akan memiliki tanggung jawab secara personal untuk mencapainya melalui keterlibatan dalam proses penyusunan anggaran.

Topik mengenai pengaruh partisipasi penyusunan anggaran terhadap kinerja manajerial itu sendiri merupakan pokok bahasan yang menarik untuk diteliti. Brownell (1982) mengemukakan alasan menariknya topik tersebut, yaitu: (1) pada umumnya partisipasi penyusunan anggaran dinilai sebagai pendekatan manajerial yang dapat meningkatkan kinerja anggota organisasi; (2) hasil penelitian yang dilakukan untuk menguji hubungan antara kedua variabel tersebut memberikan hasil yang tidak konsisten antara satu peneliti dengan peneliti lainnya.

Berdasarkan uraian tersebut, maka dirumuskan hipotesis pertama $\left(\mathrm{H}_{1}\right)$ dalam penelitian ini yakni:

$H_{1}:$ Partisipasi penyusunan anggaran berpengaruh positif dan signifikan terhadap kinerja manajerial 


\section{Pengaruh Partisipasi Penyusunan Anggaran terhadap Kinerja Manajerial dengan}

Motivasi sebagai Variabel Moderating

Motivasi juga menunjukkan derajat sampai sejauhmana individu ingin dan berusaha untuk melaksanakan suatu pekerjaan dengan baik (Mitchell, 1982), serta sebagai kesediaan untuk mengeluarkan tingkat upaya yang tinggi ke arah pencapaian tujuan organisasi, yang dikondisikan oleh kemampuan upaya tersebut dalam memenuhi kebutuhan individual (Robbins, 2014).

Dalam penelitian ini teori harapan (expectancy theory) menjelaskan bahwa motivasi sangat berpengaruh pada sikap individu dalam melaksanakan pekerjaannya. Teori harapan (expectancy theory) itu sendiri merupakan salah satu teori motivasi yang menekankan pada pemahaman mengenai tujuan individu dan pertautan antara upaya dan kinerja, antara kinerja dan imbalan/ganjaran, serta pada akhirnya antara imbalan/ganjaran dan dipuaskannya tujuan/kebutuhan individu. Jika dikaitkan dengan partisipasi penyusunan anggaran, teori ini menyatakan bahwa tingkat partisipasi individu yang tinggi dalam proses penyusunan anggaran diharapkan akan menghasilkan tingkat kinerja yang tinggi dan dimotivasi oleh harapan individu tersebut dalam hal memperoleh imbalan untuk memenuhi tujuan/kebutuhan pribadinya. Menurut Festinger (1957) melalui teori cognitive dissonance, menyatakan bahwa pegawai yang memiliki motivasi lebih baik (tinggi) akan memperbaiki kesalahan atau rasa kekhawatiran psikologisnya jika kinerja mereka rendah (dibawah tingkat pengharapannya). Untuk mengurangi kesalahan dan rasa kekhawatiran tersebut, maka mereka mencoba secara sukarela untuk memperbaiki kinerja mereka (Calder and Ross, 1976; Hammer and Organ, 1978). Dengan demikian apabila dikaitkan dengan partisipasi penyusunan anggaran, maka proses penyusunan anggaran yang melibatkan para manajer yang memiliki tingkat motivasi yang tinggi akan memperlihatkan adanya perbaikan kinerja, sebaliknya proses penyusunan anggaran yang melibatkan para manajer yang memiliki tingkat motivasi rendah akan memperlihatkan kinerja yang rendah pula (Mia, 1988). yakni:

Berdasarkan uraian tersebut, maka dirumuskan hipotesis kedua $\left(\mathrm{H}_{2}\right)$ dalam penelitian ini

\section{$\mathrm{H}_{2}:$ Motivasi memperkuat pengaruh partisipasi penyusunan anggaran terhadap kinerja manajerial}

\section{Pengaruh Partisipasi Penyusunan Anggaran terhadap Kinerja Manajerial dengan Komitmen Organisasi sebagai Variabel Moderating}

Komitmen organisasi adalah ikatan keterlibatan individu dengan organisasi (Mathieu and Zajac, 1990). Selain itu, komitmen organisasi juga merupakan alat bantu psikologis bagi individu dalam menjalankan kepentingan organisasinya untuk pencapaian kinerja yang diharapkan (Nouri and Parker, 1996; McClurg; 1999; Chong and Chong, 2002; Wentzel; 2002).

Berdasarkan teori penetapan tujuan (goal-setting theory) diasumsikan bahwa individu telah menentukan tujuan atas perilakunya di masa depan, dan tujuan tersebut akan mempengaruhi perilaku yang sesungguhnya. Dengan kata lain, teori ini menyatakan bahwa perilaku individu diatur oleh ide/pemikiran dan niat yang dimilikinya untuk mencapai tujuan/tingkat kinerja yang diharapkan. Tujuan/tingkat kinerja tersebut akan menentukan pilihan tindakan yang akan dilakukan yang kemudian akan menentukan seberapa besar usaha untuk mencapainya. Semakin tinggi komitmen seorang individu dalam mencapai tujuannya akan mendorong individu tersebut untuk melakukan usaha yang semakin keras. Sehingga dapat dikatakan bahwa tujuan yang dimiliki oleh seorang individu akan sangat mempengaruhi tindakannya, hal ini dapat dinilai sebagai motivasi yang kuat dalam mewujudkan kinerja yang diharapkan. Semakin tinggi komitmen organisasi yang dimiliki oleh seseorang diharapkan dapat mempengaruhi tindakannya untuk mencapai tujuannya dalam mempertahankan keanggotaannya tersebut, sehingga ia akan berusaha keras untuk mencapainya, dengan demikian kinerjanya pun dapat mengalami peningkatan. yakni:

Berdasarkan uraian tersebut, maka dirumuskan hipotesis ketiga $\left(\mathrm{H}_{3}\right)$ dalam penelitian ini

$\mathrm{H}_{3}$ : Komitmen organisasi memperkuat pengaruh partisipasi penyusunan anggaran terhadap kinerja manajerial

4. Pengaruh Partisipasi Penyusunan Anggaran terhadap Kinerja Manajerial dengan Job Relevant Information sebagai Variabel Moderating

Job relevant information (JRI) merupakan informasi yang dapat membantu manajer dalam memilih tindakan terbaik melalui informed effort yang lebih baik (Kren, 1992). Dengan kata lain, JRI merupakan informasi utama yang berhubungan dengan tugas yang dapat membantu manajer melalui 
informasi mengenai kondisi organisasi, misalnya informasi tentang tingkat perekonomian, keuangan organisasi, pemasaran, dan lain-lain sehingga dapat memberi pengetahuan yang lebih baik kepada manajer mengenai alternatif keputusan dan tindakan yang dibutuhkan untuk pencapaian kinerja serta tujuan organisasi secara lebih efektif dan efisien.

Partisipasi anggaran pada dasarnya merupakan perwujudan dari bentuk keterlibatan seluruh tingkatan manajer dalam proses penyusunan anggaran yang dinilai dapat meningkatkan kinerja manajerial (Milani, 1975). Apabila dikaitkan dengan JRI, dalam proses penyusunan anggaran itu sendiri memungkinkan terjadinya pertukaran informasi antar tingkatan manajemen. Ketersediaan informasi-informasi yang berhubungan dengan tugas (JRI) tersebut selama proses partisipasi penyusunan anggaran dapat meningkatkan kemampuan individual terhadap kinerjanya, karena JRI dapat memfasilitasi manajer dalam memberikan prediksi akurat atas kondisi lingkungan organisasi, serta menentukan tindakan terbaik melalui alternatif pilihan yang paling efektif dan efisien dalam pencapaian kinerja dan tujuan organisasi. Menurut Saraswati (2015), partisipasi penyusunan anggaran yang dilakukan oleh manajer yang memiliki akses baik terhadap informasi yang akurat dan lengkap mengenai tugas akan meningkatkan kinerja manajerialnya dalam mencapai target anggaran yang ditetapkan.

Berdasarkan uraian tersebut, maka dirumuskan hipotesis keempat $\left(\mathrm{H}_{4}\right)$ dalam penelitian ini yakni:

\section{$H_{4}:$ Job relevant information (JRI) memperkuat pengaruh partisipasi penyusunan anggaran terhadap kinerja manajerial}

\section{Metode Penelitian}

Jenis penelitian ini merupakan penelitian survey dengan pendekatan asosiatif kuantitatif. Jenis data dalam penelitian ini merupakan data subyek yang diperoleh langsung dari sumber asli (data primer). Data tersebut berupa persepsi dari subyek penelitian (responden) yang dikumpulkan melalui metode survey menggunakan kuesioner yang disebarkan kepada para responden. Sampel dalam penelitian ini diambil dengan menggunakan metode purposive sampling. Berdasarkan metode tersebut, maka jumlah sampel yang diambil adalah sejumlah 211 orang pejabat sruktural yang tersebar pada 13 PTS di Provinsi Gorontalo. Adapun metode analisis data yang digunakan dalam penelitian ini adalah moderated regression analysis (MRA). Moderated regression analysis (MRA) di dalam penelitian ini digunakan untuk menentukan pengaruh antar variable dalam penentuan hipotesis-hipotesis. Persamaan-persamaan regresi yang digunakan dalam penelitian ini diuji dengan signifikansi 5\%, model persamaan regresi penelitian ini adalah:

$$
\begin{aligned}
& Y=\propto+\beta_{1} X_{1}+\varepsilon \\
& Y=\propto+\beta_{1} X_{1}+\beta_{2} X_{2}+\beta_{3} X_{3}+\beta_{4} X_{4}+\varepsilon \\
& Y=\propto+\beta_{1} X_{1}+\beta_{2} X_{2}+\beta_{3} X_{3}+\beta_{4} X_{4}+\beta_{5} X_{1} X_{2}+\beta_{6} X_{1} X_{3}+\beta_{7} X_{1} X_{4}+\varepsilon \\
& \text { Keterangan: }
\end{aligned}
$$

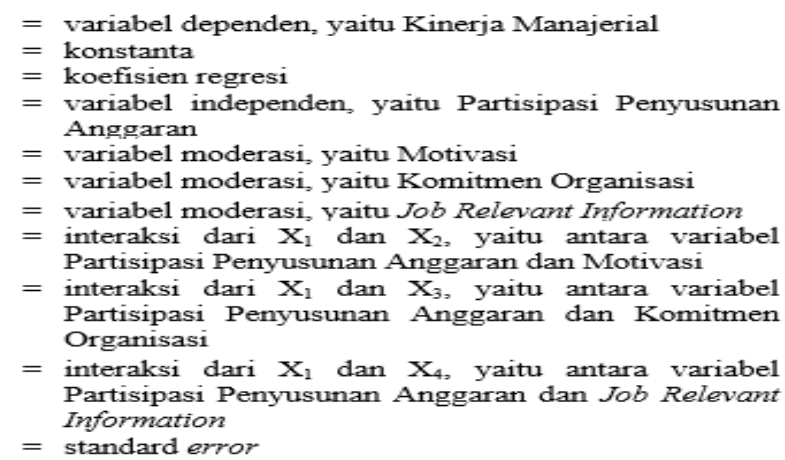

\section{Hasil Penelitian dan Pembahasan}

Penelitian ini mengambil objek perguruan tinggi swasta (PTS) di Provinsi Gorontalo yang bernaung di bawah koordinasi Kopertis IX Sulawesi yang berjumlah 13 perguruan tinggi swasta yang terdiri dari 3 Universitas, 8 Sekolah Tinggi, 1 Akademi dan 1 Politeknik. Sebanyak 211 buah kuesioner disebarkan kepada para pejabat struktural yang tersebar pada 13 PTS di Provinsi Gorontalo. Dari jumlah kuesioner yang disebarkan tersebut, terdapat 129 buah kuesioner yang dikembalikan. Sehingga kuesioner yang digunakan untuk diolah adalah sebanyak 129 buah yakni dengan presentase sebesar $61,14 \%$. Hasil analisis statistik deskriptif untuk variabel-variabel penelitian ini disajikan pada Tabel 1 berikut. 
Tabel 1.

Statistik Deskriptif Variabel Penelitian

\begin{tabular}{|l|c|c|c|c|c|c|}
\hline \multicolumn{1}{|c|}{ Variabel Penelitian } & N & $\begin{array}{c}\text { Kisaran } \\
\text { Teoritis }\end{array}$ & $\begin{array}{c}\text { Kisaran } \\
\text { Aktual }\end{array}$ & $\begin{array}{c}\text { Rata- } \\
\text { rata }\end{array}$ & $\begin{array}{c}\text { Nilai } \\
\text { Tengah }\end{array}$ & $\begin{array}{c}\text { Standar } \\
\text { Deviasi }\end{array}$ \\
\hline Partisipasi Penyusunan Anggaran $\left(\mathrm{X}_{1}\right)$ & 129 & $6-30$ & $11-30$ & 22,31 & 23 & 4,330 \\
\hline Motivasi $\left(\mathrm{X}_{2}\right)$ & 129 & $19-95$ & $55-95$ & 79,05 & 80 & 8,825 \\
\hline Komitmen Organisasi $\left(\mathrm{X}_{3}\right)$ & 129 & $12-60$ & $30-60$ & 46,92 & 48 & 7,320 \\
\hline Job Relevant Information $(\mathrm{JRI})\left(\mathrm{X}_{4}\right)$ & 129 & $10-50$ & $25-50$ & 38,25 & 39 & 5,493 \\
\hline Kinerja Manajerial (Y) & 129 & $8-40$ & $16-40$ & 30,40 & 31 & 4,560 \\
\hline
\end{tabular}

Sumber: Data Hasil Olahan SPSS (2017)

Berdasarkan Tabel 1. dari jawaban 129 responden tentang partisipasi penyusunan anggaran dihasilkan kisaran aktual yakni 11 - 30, dengan kisaran teoritis 6 - 30. Artinya tingkat partisipasi terendah responden dalam penyusunan anggaran berada pada kisaran 11 dan tingkat partisipasi tertinggi responden dalam penyusunan anggaran berada pada kisaran 30, sedangkan kisaran yang mungkin terjadi adalah antara 6 (partisipasi paling rendah) sampai 30 (partisipasi paling tinggi). Angka tersebut menunjukkan bahwa ada pejabat struktural Perguruan Tinggi Swasta (PTS) yang menjadi responden dalam penelitian ini memiliki partisipasi penyusunan anggaran pada tingkat ekstrem (paling tinggi). Nilai rata-rata sebesar 22,31, nilai tengah sebesar 23, dan standar deviasi sebesar 4,330; ini berarti bahwa jawaban responden menyebar ke dalam enam kategori dan responden cenderung memiliki tingkat partisipasi yang relatif sedang atau cukup dalam proses penyusunan anggaran, ditunjukkan oleh nilai rata-rata yang tidak berbeda jauh dengan nilai tengahnya.

Selanjutnya untuk variabel motivasi dapat dilihat bahwa, dari jawaban 129 responden dihasilkan kisaran aktual yakni 55 - 95, dengan kisaran teoritis 19 - 95. Artinya tingkat motivasi terendah responden berada pada kisaran 55 dan tingkat motivasi tertinggi responden berada pada kisaran 95, sedangkan kisaran yang mungkin terjadi adalah antara 19 (motivasi paling rendah) sampai 95 (motivasi paling tinggi). Angka tersebut menunjukkan bahwa ada pejabat struktural Perguruan Tinggi Swasta (PTS) yang menjadi responden dalam penelitian ini yang memiliki motivasi pada tingkat ekstrem (paling tinggi). Nilai rata-rata sebesar 79,05, nilai tengah sebesar 80, dan standar deviasi sebesar 8,825; ini berarti bahwa jawaban responden menyebar ke dalam sembilan belas kategori dan responden cenderung memiliki motivasi yang relatif sedang atau cukup, ditunjukkan oleh nilai rata-rata yang tidak berbeda jauh dari nilai tengahnya.

Adapun untuk variabel komitmen organisasi dapat dilihat bahwa, dari jawaban 129 responden dihasilkan kisaran aktual yakni $30-60$, dengan kisaran teoritis $12-60$. Artinya tingkat komitmen organisasi terendah responden berada pada kisaran 30 dan tingkat motivasi tertinggi responden berada pada kisaran 60, sedangkan kisaran yang mungkin terjadi adalah antara 12 (komitmen organisasi paling rendah) sampai 60 (komitmen organisasi paling tinggi). Angka tersebut menunjukkan bahwa ada pejabat struktural Perguruan Tinggi Swasta (PTS) yang menjadi responden dalam penelitian ini yang memiliki komitmen organisasi pada tingkat ekstrem (paling tinggi). Nilai rata-rata sebesar 46,92, nilai tengah sebesar 48, dan standar deviasi sebesar 7,320; ini berarti bahwa jawaban responden menyebar ke dalam dua belas kategori dan responden cenderung memiliki komitmen organisasi yang relatif sedang atau cukup, ditunjukkan oleh nilai rata-rata yang tidak berbeda jauh dengan nilai tengahnya.

Berikutnya, untuk variabel job relevant information dapat dilihat bahwa, dari jawaban 129 responden dihasilkan kisaran aktual yakni 25 - 50, dengan kisaran teoritis $10-50$. Artinya tingkat JRI terendah responden berada pada kisaran 25 dan tingkat JRI tertinggi responden berada pada kisaran 50, sedangkan kisaran yang mungkin terjadi adalah antara 10 (JRI paling rendah) sampai 50 (JRI paling tinggi). Angka tersebut menunjukkan bahwa ada pejabat struktural Perguruan Tinggi Swasta (PTS) yang menjadi responden dalam penelitian ini yang memiliki akses terhadap JRI pada tingkat ekstrem (paling tinggi). Nilai rata-rata sebesar 38,25, nilai tengah sebesar 39, dan standar deviasi sebesar 5,493; ini berarti bahwa jawaban responden menyebar ke dalam sepuluh kategori dan responden cenderung memiliki akses terhadap JRI yang relatif sedang atau cukup, ditunjukkan oleh nilai rata-rata yang tidak berbeda jauh dengan nilai tengahnya.

Kemudian untuk variabel kinerja manajerial dapat dilihat bahwa, dari jawaban 129 responden dihasilkan kisaran aktual yakni $16-40$, dengan kisaran teoritis $8-40$. Artinya tingkat kinerja manajerial terendah responden berada pada kisaran 16 dan tingkat kinerja manajerial tertinggi 
responden berada pada kisaran 40, sedangkan kisaran yang mungkin terjadi adalah antara 8 (kinerja paling rendah) sampai 40 (kinerja paling tinggi). Angka tersebut menunjukkan bahwa ada pejabat struktural Perguruan Tinggi Swasta (PTS) yang menjadi responden dalam penelitian ini yang memiliki kinerja manajerial pada tingkat ekstrem (paling tinggi). Nilai rata-rata sebesar 30,40, nilai tengah sebesar 31, dan standar deviasi sebesar 4,560; ini berarti bahwa jawaban responden menyebar ke dalam delapan kategori dan responden cenderung memiliki tingkat kinerja manajerial yang relatif sedang atau cukup, ditunjukkan oleh nilai rata-rata yang tidak berbeda jauh dengan nilai tengahnya.

\section{Hasil Uji Asumsi Klasik \\ Uji Normalitas}

Uji normalitas dilakukan dengan tujuan untuk menguji apakah dalam model regresi, variabel dependen dan variabel independen semuanya mempunyai distribusi normal ataukah tidak. Uji normalitas dalam penelitian ini dilakukan dengan uji Kolmogorov-Smirnov dan analisis grafik Normal P-P Plot.

Uji normalitas dengan metode Kolmogorov-Smirnov dapat dideteksi dengan melihat nilai signifikansi residual. Jika signifikansi lebih dari 0,05 maka hal tersebut menunjukkan bahwa residual terdistribusi secara normal, dengan demikian memenuhi asumsi normalitas. Hasil uji KolmogorovSmirnov menyatakan bahwa nilai signifikansi Kolmogorov-Smirnov dari unstandarized residual adalah sebesar 0,200 yang berarti nilai ini lebih besar dari 0,05. Dengan demikian melalui uji Kolmogorov-Smirnov dapat disimpulkan bahwa residual terdistribusi secara normal dan memenuhi asumsi normalitas.

Sedangkan uji normalitas dengan metode grafik Normal P-P Plot dapat dideteksi dengan melihat penyebaran data (titik) pada sumbu diagonal grafik. Jika data menyebar di sekitar garis dan mengikuti arah sumbu diagonalnya, maka hal tersebut menunjukkan bahwa residual pada model regresi tersebut terdistribusi secara normal, dengan demikian model regresi memenuhi asumsi normalitas. Hasil uji normalitas dengan metode grafik Normal P-P Plot.

Pada grafik Normal P-Plot titik-titik menyebar di sekitar garis diagonal, serta penyebarannya mengikuti arah garis diagonal. Artinya, residual pada model regresi tersebut terdistribusi secara normal dan memenuhi asumsi normalitas. Dengan demikian melalui metode grafik Normal P-P Plot dapat disimpulkan bahwa model regresi ini layak digunakan karena memenuhi asumsi normalitas.

\section{Uji Multikolinearitas}

Uji multikolinearitas bertujuan untuk menguji apakah dalam model regresi ditemukan adanya korelasi yang tinggi antara variabel independen. Model regresi yang baik seharusnya tidak terjadi korelasi yang tinggi di antara variabel independen.

Hasil uji multikolinearitas menunjukkan bahwa nilai tolerance dari masing-masing variabel independen lebih dari 0,1 dan nilai VIF dari masing-masing variabel independen kurang dari 10, yaitu nilai tolerance untuk variabel partisipasi penyusunan anggaran $\left(\mathrm{X}_{1}\right)$ adalah sebesar $0,757>0,1$ dan nilai VIF $1,332<10$; nilai tolerance untuk variabel motivasi $\left(\mathrm{X}_{2}\right)$ adalah sebesar $0,739>0,1$ dan nilai VIF $1,352<10$; nilai tolerance untuk variabel komitmen organisasi $\left(\mathrm{X}_{3}\right)$ adalah sebesar $0,405>0,1$ dan nilai VIF $2,468<10$; dan nilai tolerance untuk variabel job relevant information $\left(\mathrm{X}_{4}\right)$ adalah sebesar 0,385 > 0,1 dan nilai VIF 2,599 < 10; dan Dengan demikian dapat disimpulkan bahwa tidak terjadi gejala multikolinearitas antara variabel partisipasi penyusunan anggaran, motivasi, komitmen organisasi, dan job relevant information.

\section{Uji Heteroskedastisitas}

Uji heteroskedastisitas bertujuan untuk menguji apakah dalam model regresi terjadi ketidaksamaan varian dari residual pada satu pengamatan ke pengamatan yang lain. Heteroskedastisitas akan memperlemah kemampuan prediksi suatu model regresi. Model regresi dikatakan baik apabila tidak terjadi heteroskedastisitas (Priyatno, 2016: 117). Uji heteroskedastisitas dalam penelitian ini dilakukan dengan menggunakan metode uji Glejser dan metode grafik Scatterplot.

Untuk mendeteksi ada tidaknya heteroskedastisitas dengan melakukan uji Glejser, yaitu dengan meregresikan absolute residual dengan masing-masing variabel independen. Jika pada uji $\mathrm{t}$ nilai signifikansi antara variabel independen dengan absolute residual lebih dari 0,05, maka tidak terjadi heteroskedastisitas. Hasil uji heteroskedastisitas variabel independen dengan uji Glejser menunjukkab bahwa nilai signifikansi uji t keempat variabel independen dengan absolute residual 
adalah lebih dari 0,05. Sehingga melalui uji Glejser dapat disimpulkan bahwa tidak ada masalah heteroskedastisitas pada model regresi ini.

Sedangkan untuk mendeteksi ada tidaknya heteroskedastisitas dengan metode grafik Scatterplot, dapat dilakukan dengan melihat ada tidaknya pola tertentu pada grafik Scatterplot antara variabel dependen (ZPRED) dengan residual (SRESID), Apabila pola grafik yang ditunjukkan oleh titik-titik dengan pola yang tidak jelas di atas dan di bawah angka nol pada sumbu Y, maka tidak terjadi masalah heterokedastisitas.

Berdasarkan hasil uji heteroskedastisitas dengan metode grafik Scatterplot, titik-titik pada grafik Scatterplot menyebar dengan pola yang tidak jelas di atas dan di bawah angka nol pada sumbu Y. Dengan demikian melalui metode grafik Scatterplot dapat disimpulkan bahwa tidak terjadi masalah heteroskedastisitas pada model regresi ini.

\section{Moderated Regression Analysis (MRA)}

Dari analisis regresi moderasi yang dilakukan menggunakan aplikasi IBM SPSS versi 22, diperoleh output berupa tabel Model Summary, ANOVA, dan Coefficients atas variabel partisipasi penyusunan anggaran $\left(\mathrm{X}_{1}\right)$, variabel motivasi $\left(\mathrm{X}_{2}\right)$, komitmen organsiasi $\left(\mathrm{X}_{3}\right)$, job relevant information $\left(\mathrm{X}_{4}\right)$ dan interaksi antara variabel partisipasi penyusunan anggaran dengan variabel motivasi $\left(\mathrm{X}_{1} \mathrm{X}_{2}\right)$, interaksi antara variabel partisipasi penyusunan anggaran dengan variabel komitmen organisasi $\left(\mathrm{X}_{1} \mathrm{X}_{3}\right)$, dan interaksi antara variabel partisipasi penyusunan anggaran dengan variabel job relevant information $\left(\mathrm{X}_{1} \mathrm{X}_{4}\right)$ terhadap variabel kinerja manajerial $(\mathrm{Y})$ yang sudah diringkas pada Tabel 2 sehingga dapat diketahui koefisien untuk persamaan regresi yang diteliti, yakni sebagai berikut.

Tabel 2.

Hasil Uji Moderated Regression Analysis

\begin{tabular}{|c|c|c|c|c|c|c|}
\hline & Variabel & $\begin{array}{c}\text { Koefisie } \\
\text { n } \\
\text { Regresi }\end{array}$ & Nilai & $\begin{array}{c}\text { Std. } \\
\text { Error }\end{array}$ & $\stackrel{\text { t- }}{\text { Hitung }}$ & $\begin{array}{l}\text { Proba } \\
\text { bilitas }\end{array}$ \\
\hline Persamaan (la) & $Y=\beta_{1} X_{1}+\varepsilon$ & & & & & \\
\hline Intercept & Konstanta & $\alpha$ & 30,403 & 0,364 & 83,580 & 0,000 \\
\hline \multirow{2}{*}{\multicolumn{7}{|c|}{$r=0,431, r^{2}=0,185$, Adjusted $r^{2}=0,179, n=129, F=28,893 ; p=0,000<0,05$}} \\
\hline & & & & & & \\
\hline Intercept & Konstanta & $\alpha$ & 30,404 & 0,249 & 121,87 & 0,000 \\
\hline $\mathrm{X}_{1}$ & asi Penyusunan Anggaran & $\beta_{1}$ & 0,058 & & 0 & \\
\hline $\mathbf{x}_{2}$ & Motivasi & $\beta_{2}$ & 0,037 & 0,033 & 0,880 & 0,263 \\
\hline $\mathbf{X}_{3}$ & Komitmen Organisasi & $\beta_{3}$ & 0,164 & 0,054 & 1,123 & 0,003 \\
\hline $\mathbf{x}_{4}$ & Job Relevant Information & $\beta_{4}$ & 0,417 & 0,074 & $\begin{array}{l}3,057 \\
5,679\end{array}$ & 0,000 \\
\hline \multicolumn{7}{|c|}{$r=0,791, r^{2}=0,626$, Adjusted $r^{2}=0,614, n=129, F=51,860 ; p=0,000<0,05$} \\
\hline \multicolumn{7}{|c|}{ Persamaan (lc) $\quad Y=\beta_{1} X_{1}+\beta_{2} X_{2}+\beta_{3} X_{3}+\beta_{4} X_{4}+\beta_{5} X_{1} X_{2}+\beta_{6} X_{1} X_{3}+\beta_{7} X_{1} X_{4}+\varepsilon$} \\
\hline Intercept & Konstanta & $\alpha$ & 30,557 & 0,269 & 113,74 & 0,000 \\
\hline $\mathbf{x}_{1}$ & Partisipasi Penyusunan Anggaran & $\beta_{1}$ & 0,066 & 0,067 & 9 & 0,325 \\
\hline $\mathbf{X}_{2}$ & Motiv & $\beta_{2}$ & 0,024 & 0,0 & 0,98 & 0,4 \\
\hline $\mathbf{X}_{3}$ & en Organisasi & $\beta_{3}$ & 0,147 & 0,054 & 0,725 & 0,007 \\
\hline $\mathrm{x}_{4}$ & Job Relevant Information & $\beta_{4}$ & 0,446 & 0,073 & 2,730 & 0,000 \\
\hline $\mathbf{X}_{1} \mathbf{X}_{2}$ & Interaksi Par_Mot & $\beta_{5}$ & 0,017 & 0,009 & 6,081 & \\
\hline $\mathbf{X}_{1} \mathbf{X}_{3}$ & Interaksi Par_Kom & $\begin{array}{l}\beta_{5} \\
\beta_{6}\end{array}$ & 0,006 & 0,011 & 1,915 & 0,548 \\
\hline $\mathbf{X}_{1} \mathbf{X}_{4}$ & Interaksi Par_JRI & $\beta_{7}$ & $-0,040$ & 0,017 & 0,603 & 0,022 \\
\hline \multicolumn{7}{|c|}{$r=0,803, r^{2}=0,645$, Adjusted $r^{2}=0,625, n=129, F=31,418 ; p=0,000<0$} \\
\hline
\end{tabular}

Sumber: Data Hasil Olahan SPSS (2017)

Dari output pada Tabel 2 tersebut diperoleh persamaan (1a), sebagai berikut.

$$
Y=30,403+0,453 X_{1}+\varepsilon
$$

Dari persamaan tersebut diperoleh nilai konstanta sebesar 30,403 yang menunjukkan bahwa apabila variabel partisipasi penyusunan anggaran $\left(\mathrm{X}_{1}\right)$ nilainya sama dengan 0 maka nilai variabel kinerja manajerial (Y) adalah sebesar 30,403 satuan dengan asumsi variabel bebas lainnya konstan. Nilai koefisien regresi variabel partisipasi penyusunan anggaran $\left(\beta_{1}\right)$ sebesar 0,453 menunjukkan bahwa, apabila nilai partisipasi penyusunan anggaran $\left(\mathrm{X}_{1}\right)$ bertambah satu satuan, maka nilai kinerja manajerial (Y) akan mengalami kenaikan sebesar 0,453 dengan asumsi variabel bebas lainnya konstan. Nilai-nilai tersebut menunjukkan bahwa arah garis persamaan ini adalah linear dan merupakan hubungan yang positif.

Dari output pada Tabel 2 tersebut juga diperoleh persamaan (1b), sebagai berikut.

$$
Y=30,404+0,058 X_{1}+0,037 X_{2}+0,164 X_{3}+0,417 X_{4}+\varepsilon
$$

Dari persamaan tersebut diperoleh nilai konstanta sebesar 30,404 yang menunjukkan bahwa, jika variabel partisipasi penyusunan anggaran, komitmen organisasi, dan job relevant information 
nilainya sama dengan 0 , maka variabel kinerja manajerial nilainya adalah sebesar 30,404 satuan dengan asumsi variabel bebas lainnya konstan. Nilai koefisien regresi variabel partisipasi penyusunan anggaran $\left(\beta_{1}\right)$ sebesar 0,058 menunjukkan bahwa, jika partisipasi penyusunan anggaran $\left(\mathrm{X}_{1}\right)$ bertambah satu satuan, maka nilai kinerja manajerial $(\mathrm{Y})$ akan mengalami peningkatan sebesar 0,058 satuan dengan asumsi variabel bebas lainnya konstan. Nilai koefisien regresi variabel motivasi $\left(\beta_{2}\right)$ sebesar 0,037 menunjukkan bahwa, jika motivasi $\left(\mathrm{X}_{2}\right)$ bertambah satu satuan, maka nilai kinerja manajerial (Y) akan mengalami peningkatan sebesar 0,037 satuan dengan asumsi variabel bebas lainnya konstan. Nilai koefisien regresi variabel komitmen organisasi $\left(\beta_{3}\right)$ sebesar 0,164 menunjukkan bahwa, jika komitmen organisasi $\left(\mathrm{X}_{3}\right)$ bertambah satu satuan, maka nilai kinerja manajerial $(\mathrm{Y})$ akan mengalami peningkatan sebesar 0,164 satuan dengan asumsi variabel bebas lainnya konstan. Nilai koefisien regresi variabel job relevant information $\left(\beta_{4}\right)$ sebesar 0,417 menunjukkan bahwa, jika job relevant information $\left(\mathrm{X}_{4}\right)$ bertambah satu satuan, maka nilai kinerja manajerial $(\mathrm{Y})$ akan mengalami peningkatan sebesar 0,417 satuan dengan asumsi variabel bebas lainnya konstan.

Dari output pada Tabel 2 tersebut juga diperoleh persamaan regresi linear berganda dari persamaan (1c), sebagai berikut.

$$
\begin{aligned}
& Y=30,557+0,066 X_{1}+0,024 X_{2}+0,147 X_{3}+0,446 X_{4}+0,017 X_{1} X_{2}+ \\
& 0,006 X_{1} X_{3}-0,040 X_{1} X_{4}+\varepsilon
\end{aligned}
$$

Dari persamaan tersebut diperoleh nilai konstanta sebesar 30,557 yang menunjukkan bahwa, jika variabel partisipasi penyusunan anggaran, komitmen organisasi, job relevant information, interaksi antara partisipasi penyusunan anggaran dengan motivasi, interaksi antara partisipasi penyusunan anggaran dengan komitmen organisasi, interaksi antara partisipasi penyusunan anggaran dengan job relevant information nilainya sama dengan 0 , maka variabel kinerja manajerial nilainya adalah sebesar 30,557 satuan dengan asumsi variabel bebas lainnya konstan. Nilai koefisien regresi variabel partisipasi penyusunan anggaran $\left(\beta_{1}\right)$ sebesar 0,066 menunjukkan bahwa, jika partisipasi penyusunan anggaran $\left(\mathrm{X}_{1}\right)$ bertambah satu satuan, maka nilai kinerja manajerial $(\mathrm{Y})$ akan mengalami peningkatan sebesar 0,066 satuan dengan asumsi variabel bebas lainnya konstan. Nilai koefisien regresi variabel motivasi $\left(\beta_{2}\right)$ sebesar 0,024 menunjukkan bahwa, jika motivasi $\left(\mathrm{X}_{2}\right)$ bertambah satu satuan, maka nilai kinerja manajerial (Y) akan mengalami peningkatan sebesar 0,024 satuan dengan asumsi variabel bebas lainnya konstan. Nilai koefisien regresi variabel komitmen organisasi $\left(\beta_{3}\right)$ sebesar 0,147 menunjukkan bahwa, jika komitmen organisasi $\left(\mathrm{X}_{3}\right)$ bertambah satu satuan, maka nilai kinerja manajerial $(\mathrm{Y})$ akan mengalami peningkatan sebesar 0,147 satuan dengan asumsi variabel bebas lainnya konstan. Nilai koefisien regresi variabel job relevant information $\left(\beta_{4}\right)$ sebesar 0,446 menunjukkan bahwa, jika job relevant information $\left(\mathrm{X}_{4}\right)$ bertambah satu satuan, maka nilai kinerja manajerial (Y) akan mengalami peningkatan sebesar 0,446 satuan dengan asumsi variabel bebas lainnya konstan. Kemudian, nilai koefisien regresi $\beta_{5}$ sebesar 0,017 yang merupakan hasil perkalian variabel partisipasi penyusunan anggaran $\left(\mathrm{X}_{1}\right)$ dengan variabel motivasi $\left(\mathrm{X}_{2}\right)$ menunjukkan bahwa, jika interaksi antara partisipasi penyusunan anggaran dengan motivasi bertambah satu satuan, maka akan meningkatkan nilai kinerja manajerial (Y) sebesar 0,017 satuan. Nilai koefisien regresi $\beta_{6}$ sebesar 0,006 yang merupakan hasil perkalian variabel partisipasi penyusunan anggaran $\left(\mathrm{X}_{1}\right)$ dengan variabel komitmen organisasi $\left(\mathrm{X}_{3}\right)$ menunjukkan bahwa, jika interaksi antara partisipasi penyusunan anggaran dengan komitmen organisasi bertambah satu satuan, maka akan meningkatkan nilai kinerja manajerial (Y) sebesar 0,006 satuan. Nilai koefisien regresi $\beta_{7}$ sebesar $-0,040$ yang merupakan hasil perkalian variabel partisipasi penyusunan anggaran $\left(\mathrm{X}_{1}\right)$ dengan variabel job relevant information $\left(\mathrm{X}_{4}\right)$ menunjukkan bahwa, jika interaksi antara partisipasi penyusunan anggaran dengan job relevant information bertambah satu satuan, maka akan nilai kinerja manajerial (Y) akan mengalami penurunan sebesar 0,040 satuan.

\section{Analisis Koefisien Determinasi $\left(\mathbf{R}^{2}\right)$}

Berdasarkan output SPSS pada Tabel 2 tersebut diketahui bahwa, nilai koefisien determinasi $\left(\mathrm{R}^{2}\right)$ pada persamaan (1a) adalah sebesar 0,185 atau $18,50 \%$. Angka tersebut berarti bahwa sebesar $18,50 \%$ Kinerja manajerial $(\mathrm{Y})$ dapat dijelaskan oleh partisipasi penyusunan anggaran $\left(\mathrm{X}_{1}\right)$. Sedangkan sisanya $(100 \%-18,50 \%=81,50 \%)$ dipengaruhi oleh variabel lain yang lain.

Kemudian nilai $\mathrm{R}^{2}$ dari persamaan (1b) adalah sebesar 0,626 atau 62,60\%. Angka tersebut memiliki arti bahwa sebesar 64,50\% kinerja manajerial (Y) dapat dijelaskan oleh variasi partisipasi penyusunan anggaran $\left(\mathrm{X}_{1}\right)$, motivasi $\left(\mathrm{X}_{2}\right)$, komitmen organisasi $\left(\mathrm{X}_{3}\right)$, dan job relevant information 
$\left(\mathrm{X}_{4}\right)$. Sedangkan sisanya $(100 \%-62,60 \%=37,40 \%)$ dipengaruhi oleh variabel lain yang lain di luar model.

Berikutnya, nilai $\mathrm{R}^{2}$ dari persamaan (1c) adalah sebesar 0,645 atau 64,50\%. Angka tersebut memiliki arti bahwa sebesar 64,50\% kinerja manajerial $(\mathrm{Y})$ dapat dijelaskan oleh variasi partisipasi penyusunan anggaran $\left(\mathrm{X}_{1}\right)$, motivasi $\left(\mathrm{X}_{2}\right)$, komitmen organisasi $\left(\mathrm{X}_{3}\right)$, job relevant information $\left(\mathrm{X}_{4}\right)$, interaksi partisipasi penyusunan anggaran dengan motivasi $\left(\mathrm{X}_{1} \mathrm{X}_{2}\right)$, interaksi partisipasi penyusunan anggaran dengan komitmen organisasi $\left(\mathrm{X}_{1} \mathrm{X}_{3}\right)$, dan interaksi partisipasi penyusunan anggaran dengan job relevant information $\left(\mathrm{X}_{1} \mathrm{X}_{4}\right)$. Sedangkan sisanya $(100 \%-64,50 \%=35,50 \%)$ dipengaruhi oleh variabel lain yang lain di luar model.

Berdasarkan output-output tersebut dapat dilihat perbandingan hasil uji koefisien determinasi, dimana nilai $R^{2}$ pada persamaan (1b) menunjukkan angka sebesar 0,626 , sedangkan nilai $R^{2}$ pada persamaan (1c) menunjukkan angka sebesar 0,645. Hasil pengujian dengan tersebut memperlihatkan adanya peningkatan nilai $\mathrm{R}^{2}$ sebesar 0,019 setelah adanya interaksi variabel independen dengan variabel moderasi. Hal ini menunjukkan bahwa variabel moderasi memang mempengaruhi hubungan variabel independen terhadap variabel dependen.

\section{Uji Signifikansi \\ Pengujian Hipotesis 1}

Berdasarkan hasil pengujian moderated regression analysis (MRA) pada Tabel 2 diperoleh nilai koefisien regresi untuk variabel partisipasi penyusunan anggaran $\left(\beta_{1}\right)$ adalah positif, sebesar 0,453 dengan nilai signifikansi $0,000<0,05$, adalah signifikan. Kesimpulan yang diperoleh atas hasil analisis tersebut yakni dapat diketahui bahwa, partisipasi penyusunan anggaran $\left(\mathrm{X}_{1}\right)$ berpengaruh positif dan signifikan terhadap kinerja manajerial $(\mathrm{Y})$. Dengan demikian hipotesis $1\left(\mathrm{H}_{1}\right)$ dalam penelitian ini diterima, yakni partisipasi penyusunan anggaran $\left(\mathrm{X}_{1}\right)$ berpengaruh positif dan signifikan terhadap kinerja manajerial (Y).

\section{Pengujian Hipotesis 2}

Berdasarkan hasil pengujian moderated regression analysis (MRA) pada Tabel 2 diperoleh nilai koefisien regresi untuk variabel motivasi $\left(\beta_{2}\right)$ sebesar 0,024 dengan nilai signifikansi $0,058>$ 0,05 , adalah tidak signifikan. Sedangkan nilai koefisien regresi untuk variabel interaksi antara partisipasi penyusunan anggran dengan variabel motivasi $\left(\beta_{5}\right)$ sebesar 0,017 dengan nilai signifikansi $0,058>0,05$, adalah tidak signifikan.

Kesimpulan yang diperoleh atas hasil analisis tersebut yakni dapat diketahui bahwa, moderasi dari variabel motivasi $\left(\mathrm{X}_{2}\right)$, memperkuat pengaruh partisipasi penyusunan anggaran $\left(\mathrm{X}_{1}\right)$ terhadap kinerja manajerial $(\mathrm{Y})$. Meskipun memperkuat, pengaruhnya tidak signifikan. Hal tersebut dilihat dari nilai koefisien regresi yang dihasilkan dari pengaruh interaksi $X_{1} X_{2}$ terhadap $Y$ adalah positif $(0,017)$ dengan tingkat signifikansi sebesar $0,058>0,05$. Selain itu, dari hasil pengujian statistik tersebut juga diperoleh informasi bahwa pada persamaan (1c), koefisien $\beta_{2}=0$ (tidak signifikan) dan koefisien $\beta_{5}=$ 0 (tidak signifikan), maka dapat disimpulkan bahwa variabel motivasi merupakan variabel homologiser moderator, artinya variabel motivasi merupakan variabel yang hanya sekedar memliki potensi menjadi variabel moderasi yang mempengaruhi kekuatan hubungan antara variabel independen dan variabel dependen.

Oleh karena hasil pengujian statistik atas interaksi partsipasi penyusunan anggaran dengan motivasi $\left(\mathrm{X}_{1} \mathrm{X}_{2}\right)$ menunjukkan hasil yang tidak signifikan, maka artinya hipotesis $2\left(\mathrm{H}_{2}\right)$ dalam penelitian ini ditolak, atau dengan kata lain motivasi $\left(\mathrm{X}_{2}\right)$ tidak memperkuat pengaruh partisipasi penyusunan anggaran $\left(\mathrm{X}_{1}\right)$ terhadap kinerja manajerial $(\mathrm{Y})$.

\section{Pengujian Hipotesis 3}

Berdasarkan hasil pengujian moderated regression analysis (MRA) pada Tabel 2 diperoleh nilai koefisien regresi untuk variabel komitmen organisasi $\left(\beta_{3}\right)$ sebesar 0,147 dengan nilai signifikansi $0,007<0,05$, adalah signifikan. Sedangkan nilai koefisien regresi untuk variabel interaksi antara partisipasi penyusunan anggran dengan variabel komitmen organisasi $\left(\beta_{6}\right)$ sebesar 0,006 dengan nilai signifikansi 0,548 >0,05, adalah tidak signifikan.

Kesimpulan yang diperoleh atas hasil analisis tersebut yakni dapat diketahui bahwa, moderasi dari variabel komitmen organisasi $\left(\mathrm{X}_{3}\right)$, memperkuat pengaruh partisipasi penyusunan anggaran $\left(\mathrm{X}_{1}\right)$ terhadap kinerja manajerial (Y). Meskipun memperkuat, pengaruhnya tidak signifikan. Hal tersebut dilihat dari nilai koefisien regresi yang dihasilkan dari pengaruh interaksi $\mathrm{X}_{1} \mathrm{X}_{3}$ terhadap $\mathrm{Y}$ adalah positif $(0,006)$ dengan tingkat signifikansi sebesar $0,548>0,05$. Selain itu, dari hasil pengujian statistik tersebut juga diperoleh informasi bahwa pada persamaan (1c), koefisien $\beta_{3} \neq 0$ (signifikan) 
dan koefisien $\beta_{6}=0$ (tidak signifikan), maka dapat disimpulkan bahwa variabel komitmen organisasi merupakan variabel predictor moderator, artinya komitmen organisasi hanya merupakan variabel yang berperan sebagai variabel prediktor (independen) dalam mempengaruhi variabel dependen.

Oleh karena hasil pengujian statistik atas interaksi partsipasi penyusunan anggaran dengan komitmen organisasi $\left(\mathrm{X}_{1} \mathrm{X}_{3}\right)$ menunjukkan hasil yang tidak signifikan, maka artinya hipotesis $3\left(\mathrm{H}_{3}\right)$ dalam penelitian ini ditolak, atau dengan kata lain komitmen organisasi $\left(\mathrm{X}_{3}\right)$ tidak memperkuat pengaruh partisipasi penyusunan anggaran $\left(\mathrm{X}_{1}\right)$ terhadap kinerja manajerial $(\mathrm{Y})$.

\section{Pengujian Hipotesis 4}

Berdasarkan hasil pengujian moderated regression analysis (MRA) pada Tabel 2 diperoleh nilai koefisien regresi untuk variabel job relevant information $\left(\beta_{4}\right)$ sebesar 0,446 dengan nilai signifikansi $0,000<0,05$, adalah signifikan. Sedangkan nilai koefisien regresi untuk variabel interaksi antara partisipasi penyusunan anggran dengan variabel job relevant information $\left(\beta_{7}\right)$ sebesar 0,040 dengan nilai signifikansi $0,022<0,05$, adalah signifikan.

Kesimpulan yang diperoleh atas hasil analisis tersebut yakni dapat diketahui bahwa, moderasi dari variabel job relevant information $\left(\mathrm{X}_{4}\right)$, memperlemah pengaruh partisipasi penyusunan anggaran $\left(\mathrm{X}_{1}\right)$ terhadap kinerja manajerial $(\mathrm{Y})$ dan pengaruhnya signifikan. Hal tersebut dilihat dari nilai koefisien regresi yang dihasilkan dari pengaruh interaksi $\mathrm{X}_{1} \mathrm{X}_{4}$ terhadap $\mathrm{Y}$ adalah negatif $(-0,040)$ dengan tingkat signifikansi sebesar $0,022<0,05$. Selain itu, dari hasil pengujian statistik tersebut juga diperoleh informasi bahwa pada persamaan (1c), koefisien $\beta_{4} \neq 0$ (signifikan) dan koefisien $\beta_{7} \neq 0$ (signifikan), maka dapat disimpulkan bahwa variabel job relevant information merupakan variabel quasi moderator, artinya job relevant information merupakan variabel yang memoderasi hubungan antara variabel independen dengan variabel dependen yang sekaligus menjadi variabel independen.

Oleh karena hasil pengujian statistik atas interaksi partsipasi penyusunan anggaran dengan job relevant information $\left(\mathrm{X}_{1} \mathrm{X}_{4}\right)$ menunjukkan hasil yang negatif dan signifikan, maka artinya hipotesis 4 $\left(\mathrm{H}_{4}\right)$ dalam penelitian ini ditolak, atau dengan kata lain job relevant information $\left(\mathrm{X}_{4}\right)$ tidak memperkuat pengaruh partisipasi penyusunan anggaran $\left(\mathrm{X}_{1}\right)$ terhadap kinerja manajerial $(\mathrm{Y})$.

\section{Pengaruh Partisipasi Penyusunan Anggaran terhadap Kinerja Manajerial}

Hasil penelitian ini menunjukkan bahwa partisipasi penyusunan anggaran berpengaruh positif dan signifikan terhadap kinerja manajerial. Interpretasi dari hasil temuan penelitian ini menunjukkan bahwa partisipasi penyusunan anggaran berpengaruh secara positif dan signifikan terhadap kinerja manajerial pejabat struktural Perguruan Tinggi Swasta di Provinsi Gorontalo. Hal ini berarti bahwa kinerja manajerial para pejabat struktural Perguruan Tinggi Swasta di Provinsi Gorontalo didukung oleh partisipasi mereka dalam proses penyusunan anggaran. Tingginya partisipasi para pejabat struktural Perguruan Tinggi Swasta di Provinsi Gorontalo dalam kegiatan penyusunan anggaran akan meningkatkan kinerja manajerial mereka.

Temuan ini juga sejalan dengan teori yang menyatakan bahwa anggaran yang penyusunannya mengikutsertakan partisipasi para pelaksana dapat digunakan untuk memotivasi mereka dalam hal melaksanakan rencana, tujuan, dan sekaligus untuk mengukur prestasi mereka (Supriyono, 2004). Kinerja dinyatakan efektif apabila tujuan anggaran tercapai dan bawahan memperoleh kesempatan untuk terlibat atau berpartisipasi dalam proses penyusunan anggaran. Dengan demikian partisipasi penyusunan anggaran dapat mendorong seseorang untuk mengidentifikasi target atau tujuan dan melaksanakan anggaran untuk pencapaian kinerja yang lebih baik. Temuan ini juga sejalan dengan goal-setting theory yang diangkat dalam penelitian ini. Goal-setting theory adalah teori yang berfokus pada identifikasi jenis tujuan agar individu mampu meningkatkan kinerjanya sesuai dengan visi dan misi organisasi itu sendiri. Pada pendekatan goal-setting theory, peningkatan kinerja manajerial dalam pelaksanaan tugas yang dihasilkan oleh tingginya partisipasi para manajer dalam kegiatan penyusunan anggaran diidentifikasikan sebagai tujuan (goal) yang diharapkan untuk dicapai, yang mana berhasil dikonfirmasi oleh temuan penelitian ini.

Temuan ini sesuai dengan penelitian sebelumnya yang dilakukan oleh Brownell and McInnes (1986) yang menyatakan bahwa partisipasi penyusunan anggaran berpengaruh positif dan signifikan terhadap kinerja manajerial. Hasil penelitiannya menunjukkan bahwa dengan adanya partisipasi yang tinggi dalam proses penyusunan anggaran meningkatkan kinerja manajerial. Temuan ini juga sesuai dengan penelitian Indriantoro (2000) yang menemukan bahwa terdapat hubungan yang positif dan signifikan antara partisipasi penyusunan anggaran dengan kinerja manajerial. Hasil penelitiannya menunjukkan bahwa semakin tinggi keterlibatan para manajer dalam kegiatan partisipasi penyusunan anggaran, maka kinerja manajerialnya juga akan meningkat. Kemudian, temuan ini juga sesuai dengan 
penilitian yang dilakukan sebelumnya oleh Suhartono (2004) yang menyatakan bahwa partisipasi penyusunan anggaran berpengaruh terhadap kinerja manajerial. Hasil penelitiannya menunjukkan bahwa dengan adanya tingkat partisipasi yang tinggi yang dilakukan oleh para kepala dinas, kepala subdinas, kepala seksi, maka akan meningkatkan kinerja manajeirial mereka.

Temuan ini tidak mendukung hasil penelitian sebelumnya mengenai pengaruh partisipasi penyusunan anggaran terhadap kinerja manajerial seperti penelitian yang dilakukan oleh Milani (1975). Hasil penelitiannya menunjukkan bahwa kinerja manajerial tidak dipengaruhi oleh keterlibatan manajer dalam partisipasi penyusunan anggaran. Selanjutnya, temuan ini pun tidak mendukung hasil penelitian sebelumnya yang dilakukan oleh Supomo dan Indriantoro (1998). Hasil penelitian tersebut memperoleh hasil bahwa partisipasi penyusunan anggaran tidak memiliki pengaruh langsung terhadap kinerja manajerial. Kemudian temuan ini juga tidak mendukung penelitian yang telah dilakukan sebelumnya oleh Marani dan Supomo (2003). Hasil penelitiannya menemukan bahwa, partisipasi penyusunan anggaran memiliki pengaruh yang negatif, namun demikian pengaruh tersebut tidak signifikan.

\section{Pengaruh Partisipasi Penyusunan Anggaran terhadap Kinerja Manajerial dengan Motivasi sebagai Variabel Moderating}

Hasil penelitian ini menunjukkan bahwa motivasi tidak memperkuat hubungan antara partisipasi penyusunan anggaran dengan kinerja manajerial. Interpretasi dari hasil temuan penelitian ini menunjukkan bahwa motivasi tidak mampu berperan sebagai variabel yang memoderasi pengaruh partisipasi penyusunan anggaran terhadap kinerja manajerial. Hal ini berarti tinggi rendahnya motivasi yang dimiliki oleh para pejabat struktural Perguruan Tinggi Swasta di Provinsi Gorontalo tidak dapat memperkuat ataupun memperlemah pengaruh partisipasi penyusunan anggaran terhadap kinerja manajerialnya.

Hasil penelitian ini tidak sejalan dengan expectancy theory (teori harapan) yang diangkat dalam penelitian ini. Teori ini pada dasarnya memberikan pemahaman mengenai tujuan individu dan pertautan antara upaya dan kinerja, antara kinerja dan imbalan/ganjaran, serta pada akhirnya antara imbalan/ganjaran dan dipuaskannya tujuan/kebutuhan individu. Dalam penelitian ini teori harapan menjelaskan bahwa motivasi sangat berpengaruh pada sikap individu dalam melaksanakan pekerjaannya. Begitu pula dalam hal partisipasi penyusunan anggaran. Adanya tingkat partisipasi individu yang tinggi dalam proses penyusunan anggaran diharapkan akan menghasilkan tingkat kinerja yang tinggi, dimotivasi oleh harapan individu tersebut dalam memperoleh imbalan untuk memenuhi tujuan/kebutuhan pribadinya. Namun temuan penelitian ini tidak mampu mengkonfirmasi pernyataan teori tersebut. Motivasi yang dimiliki pejabat struktural Perguruan Tinggi Swasta di Provinsi Gorontalo ternyata tidak dapat memperkuat pengaruh partisipasi penyusunan anggaran terhadap kinerja manajerial pejabat struktural Perguruan Tinggi Swasta di Provinsi Gorontalo.

Alasan sehubungan dengan tidak berhasilnya penelitian ini dalam mendukung hipotesis $2\left(\mathrm{H}_{2}\right)$ adalah karena pihak Perguruan Tinggi Swasta di Provinsi Gorontalo kurang memperhatikan aspek imbalan/ganjaran yang seharusnya diberikan kepada para pegawainya. Dengan adanya imbalan/ganjaran, akan memberikan motivasi kepada para pegawai termasuk para pejabat struktural untuk melaksanakan pekerjaannya dengan baik. Apabila mereka melaksanakan pekerjaan dengan baik maka barulah kinerja yang baik pun akan tercapai. Selain itu, dari pengertian motivasi yang dikemukakan oleh Mitchell (1982) terungkap bahwa motivasi yang ada pada masing-masing manajer akan berbeda-beda. Perbedaan tersebut dipengaruhi oleh faktor-faktor lain baik dari internal maupun eksternal misalnya faktor kepribadian (personality).

Temuan ini sesuai dengan penelitian sebelumnya yang dilakukan oleh Riyadi (1998). Hasil penelitiannya menunjukkan bahwa interaksi antara motivasi dan partisipasi penyusunan anggaran tidak berpengaruh langsung terhadap kineja manajerial, artinya motivasi tidak memoderasi pengaruh partisipasi penyusunan anggaran terhadap kinerja manajerial. Selanjutnya, temuan ini juga sesuai dengan penelitian Poerwati (2001). Hasil penelitiannya menunjukkan bahwa, kombinasi kesesuaian antara partisipasi penyusunan anggaran dan motivasi yang dimiliki manajer bukan merupakan kesesuaian terbaik, yaitu variabel motivasi tidak memenuhi prasyarat kondisional atau efektivitas dari partisipasi penyusunan anggaran sehingga tidak dapat meningkatkan kinerja manajerial. Hal tersebut berarti bahwa variabel motivasi tidak dapat berperan sebagai variabel moderating yang mempengaruhi hubungan antara partisipasi penyusunan anggaran dan kinerja manajerial. Kemudian temuan ini juga mendukung penelitian yang dilakukan oleh Suwarno (2011) dan Hikmah (2015) yang menyatakan 
bahwa motivasi tidak memoderasi pengaruh partisipasi penyusunan anggaran terhadap kinerja manajerial.

Temuan ini tidak mendukung hasil penelitian sebelumnya mengenai peran motivasi dalam memoderasi pengaruh partisipasi penyusunan anggaran terhadap kinerja manajerial seperti penelitian Mia (1988). Hasil penelitiannya menunjukkan bahwa motivasi secara signifikan berfungsi sebagai variabel moderasi dalam pengaruh partisipasi penyusunan anggaran terhadap kinerja manajerial. Adapun perbedaan penelitian ini dengan penelitian Mia (1988) adalah terletak pada objek penelitian, dimana penelitian ini dilakukan pada organisasi nirlaba yaitu Perguruan Tinggi Swasta yang bersifat nirlaba sedangkan penelitian Mia (1988) dilakukan pada perusahaan manufaktur yang bertujuan untuk memperoleh laba.

\section{Pengaruh Partisipasi Penyusunan Anggaran terhadap Kinerja Manajerial dengan Komitmen Organisasi sebagai Variabel Moderating}

Hasil penelitian ini menunjukkan bahwa komitmen organisasi tidak memperkuat hubungan antara partisipasi penyusunan anggaran dengan kinerja manajerial. Interpretasi dari hasil temuan penelitian ini menunjukkan bahwa komitmen organisasi tidak mampu berperan sebagai variabel yang memoderasi pengaruh partisipasi penyusunan anggaran terhadap kinerja manajerial. Hal ini berarti tinggi rendahnya komitmen terhadap organisasi yang dimiliki oleh para pejabat sruktural Perguruan Tinggi Swasta di Provinsi Gorontalo tidak dapat memperkuat ataupun memperlemah pengaruh partisipasi penyusunan anggaran terhadap kinerja manajerialnya.

Temuan ini tidak sejalan dengan goal setting theory (teori penetapan tujuan) yang diangkat dalam penelitian ini. Dalam teori ini diasumsikan bahwa individu telah menentukan tujuan atas perilakunya di masa depan, dan tujuan tersebut akan mempengaruhi perilaku yang sesungguhnya. Dengan kata lain, teori ini menyatakan bahwa perilaku individu diatur oleh ide/pemikiran dan niat yang dimilikinya untuk mencapai tujuan/tingkat kinerja yang diharapkan. Tujuan/tingkat kinerja tersebut akan menentukan pilihan tindakan yang akan dilakukan yang kemudian akan menentukan seberapa besar usaha untuk mencapainya. Semakin tinggi komitmen seorang individu dalam mencapai tujuannya akan mendorong individu tersebut untuk melakukan usaha yang semakin keras. Sehingga dapat dikatakan bahwa tujuan yang dimiliki oleh seorang individu akan sangat mempengaruhi tindakannya, hal ini dapat dinilai sebagai motivasi yang kuat dalam mewujudkan kinerja yang diharapkan. Komitmen organisasi sendiri merupakan tingkat keyakinan sejauh mana seseorang memihak pada suatu organisasi tertentu yang tujuannya berniat untuk memelihara keanggotaannya dalam organisasi itu. Semakin tinggi komitmen organisasi yang dimiliki oleh seseorang diharapkan dapat mempengaruhi tindakannya untuk mencapai tujuannya dalam mempertahankan keanggotaannya tersebut, sehingga ia akan berusaha keras untuk mencapainya, dengan demikian kinerjanya pun dapat mengalami peningkatan.

Adanya tingkat partisipasi individu yang tinggi dalam proses penyusunan anggaran diharapkan akan menghasilkan tingkat kinerja yang tinggi, dengan didorong oleh keinginan kuat individu tersebut dalam mempertahankan keanggotaannya dalam organisasi yang bersangkutan. Namun, temuan penelitian ini tidak mampu mengkonfirmasi pernyataan teori tersebut. Komitmen organisasi yang dimiliki pejabat struktural Perguruan Tinggi Swasta di Provinsi Gorontalo ternyata tidak dapat memperkuat pengaruh partisipasi penyusunan anggaran terhadap kinerja manajerial pejabat struktural Perguruan Tinggi Swasta di Provinsi Gorontalo.

Alasan sehubungan dengan tidak berhasilnya penelitian ini dalam mendukung hipotesis $3\left(\mathrm{H}_{3}\right)$ disebabkan oleh karena kurangnya komitmen yang dimiliki para pejabat struktural Perguruan Tinggi Swasta di Provinsi Gorontalo terhadap organisasinya. Hal ini dapat disebabkan karena adanya penilaian dari diri pejabat struktural sendiri yang merasa bahwa tujuan dan nilai-nilai organisasi tidak sesuai dengan tujuan dan nilai-nilai pribadi yang ia miliki, sehingga hal ini menimbulkan kurangnya keinginan pejabat struktural untuk bekerja keras meraih tujuannya agar dapat tetap bertahan di dalam organisasi tersebut.

Temuan ini sesuai dengan penelitian sebelumnya yang dilakukan oleh Mongeri (2013) yang menyatakan bahwa komitmen organisasi tidak memoderasi pengaruh partisipasi penyusunan anggaran terhadap kinerja manajerial. Hasil penelitiannya tidak memberikan bukti empiris mengenai komitmen organisasi yang berorientasi pada orang dalam upaya mencapai efektivitas partisipasi penyusunan anggaran untuk meningkatkan kinerja pemerintah daerah.

Temuan ini tidak mendukung hasil penelitian sebelumnya mengenai peran komitmen organisasi dalam memoderasi pengaruh partisipasi penyusunan anggaran terhadap kinerja manajerial 
seperti penelitian Sumarno (2005). Hasil penelitiannya menunjukkan bahwa komitmen organisasi secara signifikan berfungsi sebagai variabel moderasi dalam pengaruh partisipasi penyusunan anggaran terhadap kinerja manajerial. Adapun perbedaan dengan penelitian ini ialah terletak pada objek penelitiannya, dimana penelitian ini dilakukan di Perguruan Tinggi Swasta sedangkan penelitian Sumarno (2005) dilakukan di kantor cabang utama perbankan.

\section{Pengaruh Partisipasi Penyusunan Anggaran terhadap Kinerja Manajerial dengan Job Relevant Information sebagai Variabel Moderating}

Hasil penelitian ini menunjukkan bahwa job relevant information memperlemah pengaruh partisipasi penyusunan anggaran terhadap kinerja manajerial. Interpretasi dari hasil temuan penelitian ini menunjukkan bahwa job relevant information (JRI) berperan sebagai variabel yang memoderasi pengaruh partisipasi penyusunan anggaran terhadap kinerja manajerial, namun moderasinya bersifat memperlemah pengaruh keduanya. Hal ini berarti semakin tinggi tingkat kesesuaian antara partsipasi penyusunan anggaran dengan job relevant information yang dimiliki oleh para pejabat struktural Perguruan Tinggi Swasta di Provinsi Gorontalo, maka akan menyebabkan menurunnya kinerja manajerial mereka. Sebaliknya, semakin rendah tingkat kesesuian antara partisipasi penyusunan anggaran dengan job relevant information yang dimiliki oleh para pejabat struktural Perguruan Tinggi Swasta di Provinsi Gorontalo, maka akan meningkatkan kinerja manajerial mereka.

Temuan ini tidak sejalan dengan teori yang menyatakan bahwa job relevant information membantu bawahan untuk memilih alternatif tindakan-tindakan yang efektif melalui informasi yang berkaitan dengan tugas sehingga kinerja manajerial akan meningkat. Kemudian apabila dikaitkan dengan partisipasi penyusunan anggaran, secara umum informasi yang tersedia selama proses penyusunan anggaran akan meningkatkan kemampuan individual terhadap kinerja (Beehr and Love, 1983). Dengan demikian, menurut teori yang dipaparkan tersebut, job relevant information seharusnya dapat memperkuat pengaruh partisipasi penyusunan anggaran terhadap kinerja manajerial. Namun, temuan penelitian ini tidak mampu mengkonfirmasi pernyataan teori tersebut. Job relevant information yang dimiliki oleh para pejabat struktural Perguruan Tinggi Swasta di Provinsi Gorontalo justru memperlemah pengaruh partisipasi penyusunan anggaran terhadap kinerja manajerial para pejabat struktural Perguruan Tinggi Swasta di Provinsi Gorontalo.

Alasan sehubungan dengan tidak berhasilnya temuan penelitian ini dalam mendukung hipotesis $4\left(\mathrm{H}_{4}\right)$, yaitu disebabkan oleh informasi yang berhubungan dengan tugas (job relevant information) yang ada pada lingkungan Perguruan Tinggi Swasta di Provinsi Gorontalo merupakan informasi yang tidak begitu mendukung efektivitas pengambilan keputusan yang terbaik bagi Perguruan Tinggi Swasta itu sendiri, khususnya informasi-informasi yang tersedia pada saat proses penyusunan anggaran. Sehingga dengan meningkatnya informasi yang seperti itu akan menyebabkan kinerja manajerial cenderung menurun. Selain itu, ketidakberhasilan temuan penelitian ini dalam mendukung hipotesis $4\left(\mathrm{H}_{4}\right)$ disebabkan karena ketersediaan dan kejelasan informasi yang berhubungan dengan tugas (job relevant information) dalam proses penyusunan anggaran pada Perguruan Tinggi Swasta di Provinsi Gorontalo memberikan dampak yang berbeda-beda kepada setiap pejabat struktural di sana, tergantung dari tujuan pribadi dari masing-masing pejabat struktural tersebut. Fenomena ini dapat dijelaskan oleh goal-setting theory (teori penetapan tujuan), dimana dalam teori ini terungkap bahwa tujuan yang dimiliki oleh seseorang akan sangat mempengaruhi tindakan atau perilakunya. Dengan demikian, seorang pejabat struktural yang memiliki komitmen tinggi terhadap pencapaian tujuan pribadinya yang sesuai dengan tujuan organisasi dapat memaksimalkan penggunaan job relevant information (JRI) untuk meningkatkan kinerja manajerialnya. Sebaliknya seorang pejabat struktural yang memiliki komitmen tinggi terhadap pencapaian tujuan pribadinya yang tidak sesuai dengan tujuan organisasi akan menyebabkan job relevant information menjadi tidak efektif dalam peningkatan kinerja manajerial dan bahkan dapat membuatnya cenderung menurun. Sehingga dengan teori ini, dapat dijelaskan mengapa job relevant information memperlemah pengaruh partisipasi penyusunan anggaran terhadap kinerja manajerial.

Temuan ini tidak mendukung hasil penelitian sebelumnya mengenai peran job relevant information dalam memoderasi pengaruh partisipasi penyusunan anggaran terhadap kinerja manajerial seperti penelitian pada penelitian yang dilakukan oleh Putra (2014). Hasil penelitiannya menunjukkan bahwa partisipasi penyusunan anggaran berpengaruh positif dan signifikan dengan job relevant information sebagai variabel moderasi. Adapun perbedaan dengan penelitian ini ialah terletak pada objek penelitian yang dilakukan Perguruan Tinggi Swasta sedangkan penelitian yang dilakukan oleh Putra (2014) dilakukan di Satuan Kerja Perangkat Desa (SKPD). 
Temuan ini juga tidak mendukung hasil penelitian yang dilakukan oleh Himawan dan Ika S. (2010). Hasil penelitiannya menunjukkan bahwa job relevant information mampu memoderasi pengaruh partisipasi penyusunan anggaran terhadap kinerja manajerial. Ketersediaan informasi yang lebih banyak terkait dengan tugas dapat meningkatkan hubungan antara partisipasi penyusunan anggaran dan kinerja manajerial. Selain itu, temuan ini pun tidak mendukung penelitian yang dilakukan oleh Sucitrawati (2017). Hasil penelitiannya menunjukkan bahwa job relevant information tidak mampu memoderasi hubungan antara partisipasi penyusunan anggaran terhadap kinerja manajerial.

\section{Penutup}

Berdasarkan hasil penelitian dan pembahasan maka dapat disimpulkan, yaitu 1) Partisipasi penyusunan anggaran berpengaruh positif dan signifikan terhadap kinerja manajerial pada Perguruan Tinggi Swasta di Provinsi Gorontalo. Hal ini berdasarkan hasil analisis yang ditunjukkan oleh koefisien regresi partisipasi penyusunan anggaran yang bernilai positif dengan nilai signifikansi sebesar 0,000 lebih kecil dari 0,005; 2) Motivasi tidak memperkuat pengaruh partisipasi penyusunan anggaran terhadap kinerja manajerial pada Perguruan Tinggi Swasta di Provinsi Gorontalo. Hal ini berdasarkan hasil analisis yang ditunjukkan oleh koefisien regresi interaksi partisipasi penyusunan anggaran dengan motivasi $\left(\mathrm{X}_{1} \mathrm{X}_{2}\right)$ yang bernilai positif dengan nilai signifikansi 0,058 lebih besar dari 0,005 ; 3) Komitmen organisasi tidak memperkuat pengaruh partisipasi penyusunan anggaran terhadap kinerja manajerial pada Perguruan Tinggi Swasta di Provinsi Gorontalo. Hal ini berdasarkan hasil analisis yang ditunjukkan oleh koefisien regresi interaksi partisipasi penyusunan anggaran dengan komitmen organisasi $\left(\mathrm{X}_{1} \mathrm{X}_{3}\right)$ yang bernilai positif dengan nilai signifikansi 0,548 lebih besar dari 0,005 ; 4) Job relevant information (JRI) memperlemah pengaruh partisipasi penyusunan anggaran terhadap kinerja manajerial pada Perguruan Tinggi Swasta di Provinsi Gorontalo. Hal ini berdasarkan hasil analisis yang ditunjukkan oleh koefisien regresi interaksi partisipasi penyusunan anggaran dengan job relevant information $\left(\mathrm{X}_{1} \mathrm{X}_{4}\right)$ yang bernilai negatif dengan nilai signifikansi 0,022 lebih kecil dari 0,005 .

Saran yang dapat diberikan bagi pihak Perguruan Tinggi Swasta di Provinsi Gorontalo yakni: 1) Kegiatan penyusunan anggaran di Perguruan Tinggi Swasta harus senantiasa melibatkan seluruh tingkatan manajer (dalam hal ini pejabat struktural), dari manajer tingkat menengah hingga manajer tingkat bawah di dalamnya; 2) Berkaitan dengan motivasi, pihak Perguruan Tinggi Swasta di Provinsi Gorontalo seharusnya dapat memotivasi para pegawainya untuk bekerja secara maksimal. Dengan cara menampung aspirasi dan keinginan para pegawai terutama yang berkaitan dengan penyusunan anggaran. Kemudian pihak Perguruan Tinggi Swasta di Provinsi Gorontalo juga seharusnya dapat menerapkan imbalan/ganjaran kepada para pegawainya atas tindakan yang mereka lakukan dalam pekerjaan; 3) Berkaitan dengan komitmen organisasi, pihak Perguruan Tinggi Swasta di Provinsi Gorontalo seharusnya dapat menanamkan tujuan dan nilai-nilai organisasi kepada setiap pegawainya termasuk kepada para pejabat strukturalnya, agar mereka memiliki komitmen yang tinggi terhadap organisasinya sehingga dapat meningkatkan kinerja manajerial mereka; 4) Berkaitan dengan job relevant information (JRI), pihak Perguruan Tinggi Swasta di Provinsi Gorontalo hendaknya dapat benar-benar menyaring informasi yang berkaitan dengan tugas yang kiranya dapat meningkatkan efektivitas pengambilan keputusan agar peningkatan tingkat kinerja yang diinginkan dapat tercapai.

\section{Daftar Pustaka}

Bass, B. M., and H. J. Leavitt. 1963. The Dimensions of Organizational Commitment. Journal of Organizational Behavior. Vol. 13, pp: 379-387.

Beehr, T. A. and K. G. Love. 1983. A Meta-Model of The Effects of Goal Characteristics, Feedback, and Role Characteristics in Human Organization. Human Relation, pp: 151-166.

Brownell, Peter. 1982. The Role of Accounting Data In Performance Evaluation, Budgetary Participation, and Organizational Effectiveness, Journal of Accounting Research, Vol. 20, No. 1, pp. 12-27.

Brownell, Peter. 1983. Leadership Style, Budgetary Participation and Managerial Behavior. Accounting, Organizations and Society. Vol. 8, No. 4, pp: 307-321.

Brownell, Peter, and Mark Hirst. 1986. Reliance on Accounting Information, Budgetary Participation, and Task Uncertainty; Tests of A Three-Way Interaction. Journal of Accounting Research. Vol. 24. No. 2 (Autumn, 1986), pp: 241-249. 
Brownell, Peter, and Morris McInnes. 1986. Budgetary Participation, Motivation, and Managerial Performance. The Accounting Review. Vol. 61. No. 4. (October, 1986), pp: 587-600.

Calder, Bobby J., Michael Ross and Chester A. Insko. 1973. Attitude Change and Attitude Attribution: Effects of Incentive, Choice, and Consequences. Journal of Personality and Social Psychology. Vol. 25. January, pp: 84.

Chong, V. K. and K. M. Chong. 2002. Budget Goal Commitment and Informational Effects of Budget Participation on Performance: A Structural Equation Modeling Approach. Behavioral Research in Accounting. Vol. 14, pp: 65-86.

Eker, M. 2009. The Impact of Budget Participation on Managerial Performance via Organizational Commitment: A Study on The Top 500 Firms in Turkey. Ankara Üniversitesi SBF Dergisi.

Festinger, Leon. 1957. A Theory of Cognitive Dissonance. California: Stanford University Press.

Hammer, W. C. and D. W. Organ. 1975. Organizational Behavior: An Applied Psychological Approach. Dallas: Business Inc.

Hansen, Don R. and Maryanne M. Mowen. 2004. Akuntansi Manajemen. Buku Satu. Alih bahasa: Dewi Fitriasari dan Deny Armos Kwary. Jakarta: Salemba Empat.

Hikmah. 2015. Pengaruh Partisipasi Penyusunan Anggaran terhadap Kinerja Manajerial dengan Motivasi sebagai Variabel Moderating (Studi Kasus Perguruan Tinggi Swasta di Kota Semarang). Jurnal Media Ekonomi dan Manajemen. Vol. 30. No. 2. Juli 2015.

Himawan, Albertus K. dan Ardianu Ika S. 2010. Pengaruh Komitmen Organisasi, Gaya Kepemimpinan, dan Job Relevant Information terhadap Hubungan antara Partisipasi Penyusunan Anggaran dan Kinerja Manajerial (Studi Empiris pada BPR di Kota Semarang. AKSES: Jurnal Ekonomi dan Bisnis.Vol. 5. No. 9. Hal: 65-79.

Indriantoro, Nur. 2000. An Emprical Study of Locus of Control and Cultural Dimensions as Moderating Variables of The Effect of Participative Budgeting on Job Performance and Job Satisfaction. Jurnal Ekonomi dan Bisnis Indonesia. Vol. 15. Januari. Hal. 97-114.

Ivanevich, J. M. 1976. Effects of Goal Setting on Performance and Satisfaction. Journal of Applied Psychology. Vol. 61 (5), pp: 605-612.

Kenis, Izzetin. 1979. Effect of Budgetary Goal Characteristic on Manajerial Attitudes and Performance. Accounting Review. October. Hal: 707-721.

Kren, Leslie. 1992. Budgetary Participation and Managerial Performance: The Impact of Information and Environmental Volatility. The Accounting Review. Milwaukee.

Kustono, A., 2003. Pengaruh Jenis Kelamin, Locus of Control, dan Motivasi terhadap Hubungan Partisipasi dalam Penyusunan Anggaran dan Kinerja Manajerial. Jurnal Ekonomi \& Keuangan. Vol 7 (2): 126-139.

Locke, E. A. and Bryan, J. 1968. Goal Setting as A Determinant of The Effects of Knowledge of Score in Performance. American Journal of Psychology, 81, pp: 398-406.

Mahoney, T. A., T. H. Jerdee and S. J. Carroll. 1963. Development of Managerial Performance: A Research Approach. Cincinatti: Southwestern Publishing Company.

Marani, Yohanes dan Bambang Supomo. 2003. Motivasi dan Pelimpahan Wewenang sebagai Variabel Moderating dalam Hubungan antara Partisipasi Penyusunan Anggaran dengan Kinerja Manajerial. Jurnal Maksi. Vol. 2. Jayapura.

Mathieu, J. and D. Zajac. 1990. A Review of Meta-Analysis of the Antecendents, Correlates and Consequences of Organizational Commitment. Psychological Bulletin. Vol. 108. No. 2, pp: 171-94.

McClurg, L.N. 1999. Organizational Commitment in The Temporary Help Service Industry. Journal of Applied Management Studies. pp: 5-26.

Medhayani, Ni Putu dan Ketut Ali Suardana. 2015. Pengaruh Partisipasi Anggaran terhadap Kinerja Manajerial dengan Self Efficacy, Desentralisasi, dan Budaya Organisasi sebagai Variabel Pemoderasi. E-Jurnal Akuntansi Universitas Udayana. 11 (1), pp: 155-170.

Mia, Lokman. 1988. Managerial Attitude, Motivation and The Effectiveness of Budget Participation. Accounting, Organizations and Society. Vol. 13, No. 5, pp: 465-475.

Milani, K. 1975. The Relationship of Participation in Budget Setting to Industrial Supervisor Performance and Attitudes: A Field Study. The Accounting Review. April; pp: 104-123.

Mitchell, Terence R. 1982. People in Organizational, an Introduction in Organizational Behavior. $2^{\text {nd }}$ Edition. Mc. Graw Hill International Book Co. Singapore.

Mongeri, Messa. 2013. Pengaruh Partisipasi Penyusunan Anggaran terhadap Kinerja Pemerintah Daerah dengan Komitmen Organisasi sebagai Variabel Moderating (Studi Empiris pada 
SKPD Pemerintah Daerah Kota Padang). Jurnal. Fakultas Ekonomi Universitas Negeri Padang.

Morse, Nancy C., and Everett Reimer. 1956. The Experimental Change of A Major Organizational Variable. The Journal of Abnormal and Social Psychology. Vol. 52(1).

Nor, Wahyudin. 2007. Desentralisasi dan Gaya Kepemimpinan sebagai Variabel Moderating dalam Hubungan antara Partisipasi Penyusunan Anggaran dan Kinerja Manajerial. Simposium Nasional Akuntansi X. Makassar, 26-28 Juli 2007.

Nouri, H. and R. J. Parker. 1996. The Effect of Organizational Commitment and Relation Between Budgetary Participation and Budgetary Slack. Behavior Research in Accounting 8. Hal. 7489.

Poerwati, Tjahjaning. 2001. Pengaruh Partisipasi Penyusunan Anggaran terhadap Kinerja Manajerial: Budaya Organisasi dan Motivasi sebagai Variabel Moderating. Tesis. Universitas Diponegoro. Semarang.

Putra, Made Aditya. 2014. Pengaruh Partisipasi dalam Penyusunan Anggaran terhadap Kinerja Manajerial pada SKPD Kabupaten Buleleng melalui Komitmen Organisasi, Kecukupan Anggaran, Komitmen Tujuan Anggaran, dan Job Relevant Information sebagai Variabel Moderating. E-Journal S1 Ak. Vol. 2. No.1.

Riyadi, Slamet. 1998. Motivasi dan Pelimpahan Wewenang sebagai Variabel Moderating dalam Hubungan antara Partisipasi Penyusunan Anggaran dan Kinerja Manajerial. Seminar Nasional Riset Akuntansi dan Bisnis. Surabaya.

Robbins, Stephen P. and Timothy A. Judge. 2014. Perilaku Organisasi (Organizational Behavior). Edisi Keenambelas. Jakarta: Salemba Empat.

Saraswati, Gita dan Pramudya Aisyah. 2015. Informasi dalam Organisasi. Edisi Pertama. Jakarta: Salemba Empat.

Sardjito, Bambang dan Osmad Muthaher. 2007. Pengaruh Partisipasi Penyusunan Anggaran terhadap Kinerja Aparat Pemerintah Daerah: Budaya Organisasi dan Komitmen Organisasi sebagai Variabel Moderating. Simposium Nasional Akuntansi X. Makassar, 26-28 Juli 2007.

Sucitrawati, I Gusti Ayu. 2017. Pengaruh Partisipasi Penganggaran terhadap Kinerja Manajerial dengan Budaya Organisasi dan Job Relevant Information sebagai Pemoderasi. E-Jurnal Akuntansi Universitas Udayana. Vol. 20.3. September. Hal: 1791-1819.

Suhartono, Ehrmann. 2004. Pengaruh Partisipasi Penyusunan Anggaran dan Kejelasan Sasaran Anggaran terhadap Kinerja Manajerial Pemerintah Daerah dengan Motivasi sebagai Variabel Pemoderasi (Studi Empiris pada Kota dan Kabupaten se-Propinsi Daerah Istimewa Yogyakarta. Tesis. Universitas Gajah Mada. Yogyakarta.

Sumarno, J. 2005. Pengaruh Komitmen Organisasi dan Gaya Kepemimpinan terhadap Hubungan antara Partisipasi Anggaran dan Kinerja Manajerial (Studi Empiris pada Kantor Cabang Perbankan Indonesia di Jakarta. Simposium Nasional Akuntansi VIII. Solo, 15-16 September 2005.

Supomo, Bambang dan Nur Indriantoro. 1998. Pengaruh Struktur dan Kultur. Organisasional terhadap Keefektifan Anggaran Partisipatif dalam Peningkatan Kinerja Manajerial: Studi Empiris pada Perusahaan Manufaktur di Indonesia. Jurnal Kelola. No. 18/VII: 61-84.

Supriyono, R. A., 2004. Pengaruh Komitmen Organisasi dan Keinginan Sosial terhadap Hubungan antara Partisipasi Anggaran dengan Kinerja Manajer. Simposium Nasional Akuntansi VII. Bali.

Suwarno. 2011. Pengaruh Partisipasi Penyusunan Anggaran terhadap Kinerja Manajerial dengan Motivasi, Pelimpahan Wewenang dan Pengetahuan Manajemen Biaya sebagai Moderating (Studi pada Satuan Kerja Perangkat Daerah (SKPD) Se-Provinsi Riau). Jurnal SOROT. Vol. 8. No. 2 (Oktober), hlm: 1-190

Stedry, A. C. 1960. Budget Control and Cost Behavior. Prentice Hall, Inc. Englewood Cliff N. J.

Wentzel, Kristin. 2002. The Influence of Fairness Perceptions and Goal Commitment on Managers' Performance in a Budget Setting. Behavioural Research in Accounting, Vol.14, pp. 247-271. 